\title{
ARSENIC STATUS AND SPECIATION IN CHICKEN HEART TISSUES
}

\author{
*I. PIZARRO', D. ROMÁN ${ }^{1}$, M.M. GÓMEZ², M.A. PALACIOS ${ }^{2}$ \\ ${ }^{1}$ Laboratory of Bioinorganic and Environmental Analytical Chemistry, Department of Chemistry. Faculty of Basic Sciences. \\ Universidad de Antofagasta, Antofagasta (Chile) \\ ${ }^{2}$ Department of Analytical Chemistry. Faculty of Chemistry. Universidad Complutense de Madrid, (Spain)
}

\section{SUMMARY}

This study evaluated the total and main arsenic species in chicken heart tissues. The experimental study was carried out using two sets of samples. In the first one, 30-day-old chickens were exposed to sodium arsenate, using spiked drinking water. These chickens grew normally and were killed after fifty days of arsenic exposure. The second sets were edible chickens were nonexposed to sodium arsenate for a parallel study. The total arsenic and arsenic species content in the exposed samples were at least twice those in the normal edible chicken. One important aspect is the capability of the heart tissues to preconcentrate the most toxic species, arsenite, in the exposed chicken. Arsenobetaine was also detected in fat in the non exposed chicken.

This study could be a way of establishing similarities and differences with humans exposed to the same As(V) species, to ascertain whether chickens can be used in arsenic metabolism evaluation and the results extrapolated to humans.

Keywords: Chicken, As species, Heart tissues

\section{INTRODUCTION}

The toxic properties of arsenic were well established many years ago and arsenic exposure has been associated with several diseases in humans depending on doses and exposure periods ${ }^{1}$.

It is well known that arsenic toxicity depends on its chemical species ${ }^{2}$ The main source of arsenic in the human diet is usually marine food, such as shellfish, marine fish, seaweed, etc.; fortunately, this As content is in its nontoxic form, such as arsenobetaine (AsB), arsenosugars and arsenolipids. However, an important source of As impact in humans comes from contaminated waters in which the most important As species is the toxic sodium arsenate [AsV)]. The arsenic concentration in most drinking waters seldom exceeds $10 \mu \mathrm{g} \mathrm{L}^{-1}$, $1-2 \mu \mathrm{g} \mathrm{L}^{-1}$ being the average concentration in natural waters ${ }^{3}$; however two orders of magnitude higher than these values have been found in India, Taiwan, Canada, Argentina and Chile ${ }^{4}$.

Detoxification mechanisms usually involve methylation processes which mainly occur in the liver and kidneys of animals. This process has been detected in mice, rabits and poultry exposed to arsenite through feed or water ${ }^{5}$. However, the methylating capacity is highly dependent on the type of animal, some of them (guinea pig, marmoset and tamarind monkeys, chimpanzee, etc.) being unable to methylate this species 6 . Man also has a reduced methylating capacity, although monomethylarsonic acid (MMA) and dimethylarsinic acid (DMA) species have been identified in urine ${ }^{7}$. Arsenic methylation in liver towards DMA from hens exposed to $\mathrm{As}_{2} \mathrm{O}_{3}$ was demonstrated for the first time by Falnoga et al. ${ }^{8}$. The authors found a preconcentration factor of As in liver tissues from exposed hens 50 times higher with respect to the non exposed.

Cardiovascular effects due chronic exposure to arsenic have been well documented in recent scientific papers ${ }^{9-12}$. Environmental factors, such as chronic exposure to arsenic, are considered key determinants of heart disease ${ }^{13}$. It is becoming increasingly evident that low-level exposure to arsenic may have important cardiovascular effects ${ }^{12}$.

A previous work ${ }^{2,6}$ demonstrated the already suspicious relation between patients living in high inorganic arsenic contaminated areas, who suffered heart attacks, and the high inorganic arsenic content found in their heart tissues. It is therefore necessary to obtain more direct evidence of the fate of arsenic in cardiovascular tissues.

The objective of the present study was to investigate the total and main As species present in chicken heart tissues exposed to controlled arsenate concentration in drinking water from the age of ten to 55 days.

\section{EXPERIMENTAL}

\section{Samples}

Sixty ten-day-old white cockerels were subjected to a diet enriched with $\mathrm{As}(\mathrm{V})$ under controlled conditions. In the first week they drank approximately $50 \mathrm{~mL}$ of $1 \mathrm{mg} \mathrm{L}^{-1} \mathrm{As}(\mathrm{V})$ (as sodium arsenate) spiked water per day. Next, they drank approximately $100 \mathrm{~mL}$ of $5 \mathrm{mg} \mathrm{L}^{-1}$ As spiked water per day. The chickens were fed with feed containing less than $10 \mu \mathrm{g} \mathrm{Kg}^{-1}$ of As. The chickens were killed after 55 days, with an average weight of two kilograms and a good appearance.

The breast fillet of all the chickens was deep frozen, lyophilised and kept frozen for further analysis. Six whole hearts were randomly selected from the above-mentioned chickens for total As determination and As speciation.

For the parallel study, six chickens were bought in a supermarket, and the fat was separated from the rest of the cardiac muscle as for the exposed chickens. Heart tissues were oven dried at $60^{\circ} \mathrm{C}$ for 2 days and then ground in an agatha mortar and stored at $-20^{\circ} \mathrm{C}$ before use.

Manipulations and procedures for sample preparation were made in a "clean laboratory" inside a laminar flow hood (Labconco, Purifier Class II, USA) using inert devices (e.g. plastic and titanium knives, agate grinding mortar) and scalpels, scissors and forceps of surgical stainless steel. After removing the titanium clasp from the tissues, the samples were rinsed with deionized water according to the UNEP protocol for biological tissues. ${ }^{14}$

\section{Instrumentation and chromatographic materials}

HG-AAS measurements were done on GBC 909 PBT equipment coupled with a GBC HG-3000 hydride generator coupled with an electrothermal mantle GBC EHG-3000 (Australia) to determine total arsenic content in the Chilean samples. One arsenic hollow cathode-boosted discharge lamp (BDL) from Photron (Australia) was used. The inductively coupled plasma mass spectrometer (ICP-MS) used as a detector after HPLC species separation was an HP 4500 (Yokogawa Analytical Systems, Tokyo, Japan). This system was fitted with a Babington glass nebuliser and a Scott double pass spray chamber cooled by a Peltier system. Single ion monitoring at $\mathrm{m} / \mathrm{z} 75$ was used to collect the data. The analytical peaks were integrated based on peak area using ICPMS software.

A PRP-X100 analytical and guard anion-exchange column (Hamilton, Reno, NV, USA) were used for HPLC-ICP-MS analysis. The column effluent was directly introduced into the nebuliser via a $250 \mathrm{~mm}$ x $0.5 \mathrm{~mm}$ (id) polytetrafluoroethylene capillary tube.

For chromatographic separations, an HPLC system (LDC Division, Riviera Beach, Florida, USA) was used as a sample pump. Air was removed from the buffers by argon degassing for $15 \mathrm{~min}$ and the buffer was filtered prior to injection. $100 \mu \mathrm{L}$ of sample were introduced through a $0.45 \mu \mathrm{m}$ nylon syringe filter into the injection valve Rheodyne 9125 (USA). 
Table 1: shows the optimized instrumental parameters for HG-AAS, ICPMS and HPLC systems.

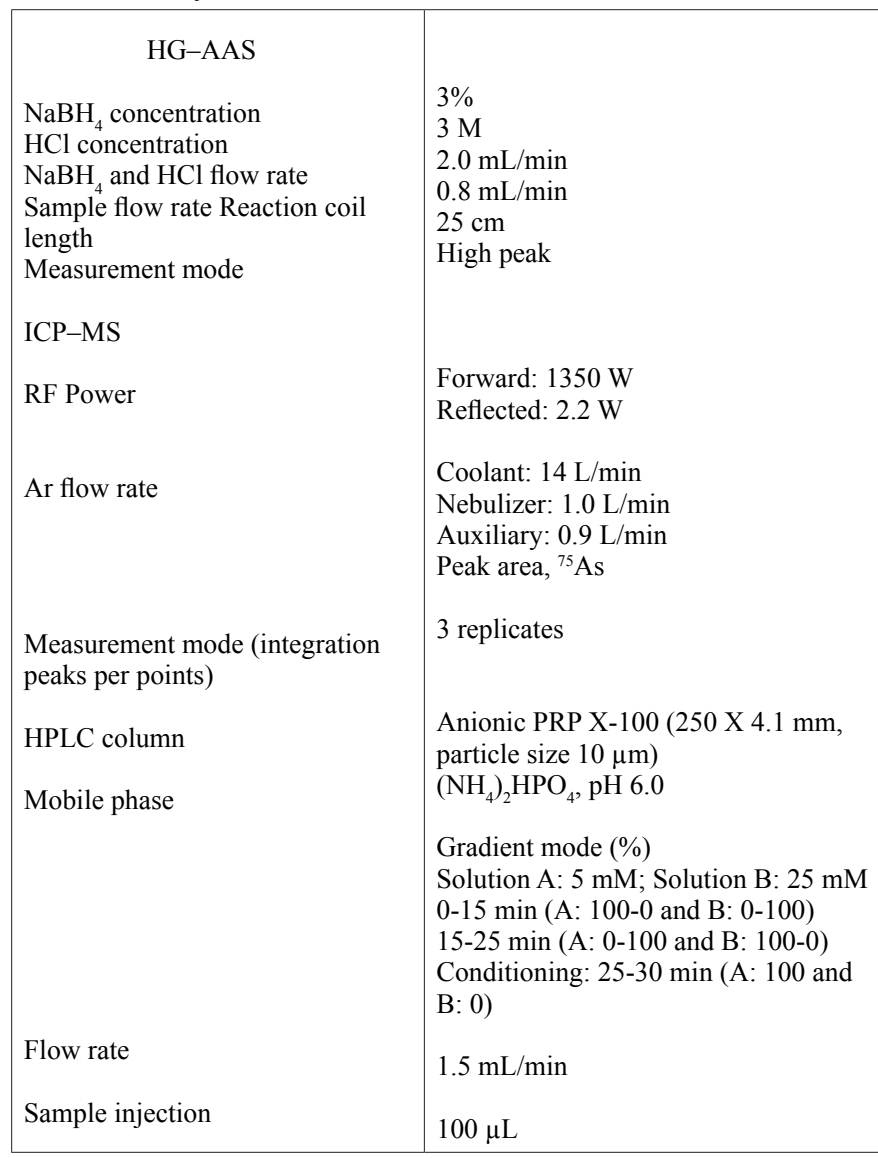

Table 1: Instrumental parameters for total As determination and As speciation analysis.

\section{Materials, reagents and standards}

The samples were mineralized in closed Teflon reactor vessels placed in an ordinary lab oven and on an aluminium hotplate.

The As species extractant mixtures were prepared from deionized water (Milli-Q Ultrapure water systems, Millipore, USA) and HPLC-grade methanol (Merck, Darmstadt, Germany). High-purity nitric and hydrochloric acids were obtained by distillation of the analytical-grade reagent (Merck) in an I.R. distiller (Berghof, BSB-939IR, Germany).

The methanol/water extracts were evaporated using a centrivap evaporator and cold trap system (Labconco, Kansas City, MO, USA). The samples were sonicated in a focused ultrasonic bath (Bandelin Sonopuls HD-2200, Fungilab S.A., USA).

Reagents such as $\mathrm{NaBH}_{4}, \mathrm{HClO}_{4}, \mathrm{Na}_{2} \mathrm{~S}_{2} \mathrm{O}_{8}, \mathrm{H}_{2} \mathrm{SO}_{4}, \mathrm{NaOH},\left(\mathrm{NH}_{4}\right) \mathrm{H}_{2} \mathrm{PO}_{4}$, $\mathrm{H}_{3} \mathrm{PO}_{4}$, were obtained from Merck (Darmstadt, Germany). Each arsenic species stock solution containing $1,000 \mathrm{~g} \mathrm{~L}^{-1}$ of As, was prepared by dissolving the respective amount of the pure compounds in water. As(III) and As(V) standards were prepared from sodium arsenite and sodium arsenate (Sigma Aldrich, St Quintin, Fallavier, France), dimethylarsinic acid (DMA) and monomethylarsonic acid (MMA) obtained from Merck, and arsenobetaine (AsB) and arsenocholine (AsC) obtained from Tri Chemical Laboratory Inc. (Japan). The stock solutions were kept at $4^{\circ} \mathrm{C}$ in the dark. Working solutions were prepared daily and then diluted with water to the final concentration. A certified reference material (National Research Council of Canada), DORM2 Dogfish muscle, was used to validate the total As content and As species determination.

\section{Total arsenic determination}

To assure the complete destruction of the fatty tissues, the sample mineralization was carried out in Teflon reactor bombs heated in a homemade refractory oven with internal temperature sensor and external control, according the two step procedure ${ }^{15}$. About $0.5-1.0 \mathrm{~g}$ of sample was attacked in the Teflon reactor bomb with $10 \mathrm{~mL}$ of concentrated $\mathrm{HNO}_{3}, 2 \mathrm{~mL}$ of concentrated $\mathrm{HClO}_{4}$ and $2 \mathrm{~mL}$ of $2 \% \mathrm{~m} / \mathrm{v} \mathrm{Na}_{2} \mathrm{~S}_{2} \mathrm{O}_{8}{ }^{15}$. Samples were pre-digested overnight at room temperature and the reactor bombs heated to $150^{\circ} \mathrm{C}$ for 2 hours in the refractory oven. After cooling, $0.5 \mathrm{~mL}$ of concentrated $\mathrm{H}_{2} \mathrm{SO}_{4}$ was added, and the digested sample heated in an aluminium heating plate from ambient to $300^{\circ} \mathrm{C}$ by semirefluxing into a $50 \mathrm{~mL}$ glass Erlenmeyer flask for 2 hours until the final volume was $2 \mathrm{~mL}$ approximately. The digested sample was diluted to $10 \mathrm{~mL}$ with 0.5 $\mathrm{M} \mathrm{HCl}$. For analysis, six sub-samples for heart muscle, six sub-samples for fat tissues and six blanks for each analysed chicken were prepared in parallel and analysed in triplicate. The total arsenic concentration was determined in each sample by HG-AAS. The operating parameters used are given in Table 1. The analytical signals were evaluated on the basis of peak height, and quantification was carried out by the standard addition method. The total arsenic in the extracts was determined by HG-AAS after mineralization of the extracts by a method similar to that described above.

The DORM-2 material was analysed following the same procedure for validation purposes.

\section{Extraction and determination of arsenic species}

Approximately $0.5 \mathrm{~g}$ of fat and $1.0 \mathrm{~g}$ of heart muscle were placed in a Teflon reactor and $10 \mathrm{~mL}$ of 1:1 methanol: water mixture was added following a treatment similar to that performed by Shibata and Morita ${ }^{16}$. The mixture was maintained at $55^{\circ} \mathrm{C}$ for 10 hours and then treated in a focussed ultrasonic bath for $5 \mathrm{~min}$ at $25^{\circ} \mathrm{C}$. The samples were centrifuged for $15 \mathrm{~min}$ at $6000 \mathrm{rpm}$ and the residue was re-extracted following the former procedure. The final residue was re-extracted with $5 \mathrm{ml}$ of 9:1 methanol:water mixture. The three combined extracts were mixed, evaporated to dryness, diluted with deionised water and filtered through a $0.45 \mu \mathrm{m}$ Nylon syringe filter and kept frozen $\left(-20^{\circ} \mathrm{C}\right)$ prior to analysis. Two extracts were prepared from each sample and three for each reference material.

The As species in the extracts were separated by HPLC under the conditions given in Table 1. The Arsenic species were detected by ICP-MS and the analytical peaks were quantified on the basis of peak area. $10 \mu \mathrm{g} \mathrm{L}{ }^{-1}{ }^{72} \mathrm{Ge}$ was used as the internal standard to correct any drift in the ICP-MS response.

Under the conditions employed, the detection limits achieved were 5, 2, 3, 2, 5 and $4 \mathrm{ng} \mathrm{g}^{-1}$ for total $\mathrm{As}, \mathrm{As}(\mathrm{III}), \mathrm{As}(\mathrm{V})$, arsenobetaine (AsB), MMA and DMA, respectively.

\section{Histological Treatment}

Histological work was done in slices of heart tissues of the two samples in which the speciation study was carried out. These samples came from one chicken of the arsenic exposure group, and one from the control group. Tissues were washed for 24 hours in deionized running water and fixed in paraffin blocks dyed with haematoxylin-eosin, Trichromic of Masson, and Orceine van Giesson stain reagents ${ }^{17}$. The histochemical methods its based on combination of chromomeric reagents with a mixture of masking agents that block tissue reactivity of tissues. The paraffnzed sections show green granulates, insoluble in water, through dissolved by acid and by ammonium hydroxide. This procedure demonstrates pretty well every practical histopathologic with additional diagnostic studies such as histological examination in microscopy scission. ${ }^{18-20}$

\section{RESULT AND DISSCUSION}

\section{Analytical validation, quality control and traceability of arsenic} measurements

For validation of the analytical methodology, total As content and As species have been quantified in the CRMs NRCC Dorm-2 (dogfish muscle). Total As content is in good agreement with their certified values. The As species concentration found in Dorm-2 (AsB: $15.09 \pm 0.5 \mu \mathrm{g} \mathrm{g}^{-1}$ As, DMA: $0.66 \pm 0.04$ $\mu \mathrm{g} \mathrm{g}^{-1} \mathrm{As}$ ) are close to those certified values (AsB: 16.4 $\pm 0.5 \mu \mathrm{g} \mathrm{g}^{-1} \mathrm{As}$ ).

Table 2 summarizes the analytic validation data to prove the suitability and efficiency of the described techniques for the determination of arsenic in heart tissues; i.e. total arsenic, total extracted arsenic with methanol-water 1:1 and 9:1 and the arsenic recovery experiments from the standard reference materials spiked with arsenic species frequently found in biological tissues, such as primary standard of As (III) and As (V) of sodium arsenite and sodium arsenate, monometilarsonic acid (MMA) and AsB. The SRMs used in these quality control approaches were, DORM-2. Detection limits were calculated in accordance with IUPAC criteria ${ }^{21,22}$. The results of the measured values of arsenic were accepted if the coefficient variation of the precision and accuracy tests were less to $15 \%$ of the accepted or certified values, respectively. Before being applied to the cardiovascular tissue samples, the arsenic speciation protocol was applied to samples of standard reference materials (Table 2). These results are very similar to those in other reports. ${ }^{23-25}$ 
Table 2. Quality control and traceability of the total As concentrations, MeOH- $\mathrm{H}_{2} \mathrm{O}$ 1:1 and 9:1 fractionated arsenic concentrations and speculated concentrations of arsenic using standard reference materials (SRM).

\begin{tabular}{|c|c|c|c|c|c|c|c|}
\hline & & Total As by HGAAS & & & & \multicolumn{2}{|c|}{$\begin{array}{l}\text { As found in } \mathrm{MeOH} \text { - Agua 1:1 } \\
\text { and } 9.1 \text { extract by HGAAS }\end{array}$} \\
\hline \multicolumn{2}{|c|}{$\mathrm{N}$} & 5 & & & & \multicolumn{2}{|l|}{5} \\
\hline \multicolumn{2}{|c|}{ SRM } & DORM-2 & & & & \multicolumn{2}{|c|}{ DORM-2 } \\
\hline \multicolumn{2}{|c|}{$\begin{array}{l}\text { Average found concentration } \\
\left(\mu \mathrm{gg}^{-1}\right)\end{array}$} & 17.0 & & & & \multicolumn{2}{|c|}{16.2} \\
\hline \multicolumn{2}{|c|}{$\begin{array}{l}\text { Certified concentration } \\
\qquad\left(\mu g^{-1}\right)\end{array}$} & 18.0 & & & & \multicolumn{2}{|c|}{18.0} \\
\hline \multicolumn{2}{|c|}{ RE (\%) } & 5.2 & & & & \multicolumn{2}{|c|}{6.7} \\
\hline \multicolumn{2}{|c|}{$\operatorname{RSD}( \pm \%)$} & 7.9 & & & & \multicolumn{2}{|c|}{8.5} \\
\hline \multicolumn{2}{|c|}{$\mathrm{C}_{\mathrm{L}}\left(\mathrm{ngmL}^{-1}\right)$} & 0.69 & & & & \multicolumn{2}{|c|}{0.20} \\
\hline SRM & $\mathrm{N}$ & As Species & Species found $\mu \mathrm{gg}^{-1}$ & $\operatorname{RSD}( \pm \%)$ & Species spiking & $\begin{array}{c}\text { Species recovery } \\
(\%)\end{array}$ & $\underset{\left(\text { ngmL }^{-1}\right)}{\mathrm{C}_{\mathrm{L}}}$ \\
\hline DORM - 2 & 3 & $\begin{array}{c}\text { As (III) } \\
\text { As (V) } \\
\text { MMA } \\
\text { DMA } \\
\text { AsB }\end{array}$ & $\begin{array}{c}\mathrm{Nd} \\
\mathrm{Nd} \\
\mathrm{Nd} \\
0.66 \\
15.1\end{array}$ & $\begin{array}{c}- \\
- \\
- \\
0.09 \\
0.8\end{array}$ & $50 \mathrm{ngmL}^{-1}$ & $\begin{array}{l}96.6 \\
95.4 \\
96.9 \\
98.9 \\
95.1\end{array}$ & $\begin{array}{l}0.02 \\
0.03 \\
0.06 \\
0.05 \\
0.03\end{array}$ \\
\hline
\end{tabular}

\section{Total As content}

Total arsenic determination in cardiac tissue is a difficult task due to the low arsenic concentration, the complexity of the matrix and the high fat content, which should be fully destroyed to avoid further interferences.

The As content in the chicken cardiac muscle and fat tissues was compared in both populations of chickens to ascertain whether there was any difference in the accumulation process depending on tissue and As exposure ${ }^{26}$. Table 3 shows the total As content in the different tissues analysed.

The content of total arsenic in exposed chicken $\left(\mathrm{EX}-\mathrm{CH}_{1-6}\right)$ was obtained for the heart muscle $\left(148.3 \mu \mathrm{g} \mathrm{Kg}^{-1}\right)$, being lower for the fat $(103.2 \mu \mathrm{g} \mathrm{Kg}$ $\left.{ }^{1}\right)$. These ratios were similar for the chicken blanks $\left(\mathrm{NE}-\mathrm{Ch}_{1-6}\right)$, although with about half the content. These results show that $\mathrm{As}(\mathrm{V})$ in drinking water is bio accumulated in chicken. However, in a medium-sized chicken of $2 \mathrm{Kg}$, the concentration found was lower than $1 \%$ of the total intake (about $22 \mathrm{mg}$ ); therefore no dramatic bioaccumulation occurred. This low As accumulation capacity may be related to a similar behaviour in mammals in which As(III) and As (V) are partly metabolized and the detoxified species (DMA and MMA,) are rapidly excreted, largely in urine ${ }^{7}$.

Table 3: Total arsenic concentration in chicken tissue $\left(\mu \mathrm{g} \mathrm{Kg}^{-1}\right)$ and arsenic extraction efficiency in 1:1 and 9:1 methanol: water (expressed as \% of total As content). $\mathrm{N}=3$.

\begin{tabular}{|c|c|c|c|c|}
\hline \multirow{3}{*}{$\begin{array}{c}\text { Tissue Sample } \\
\text { EX-Ch }\end{array}$} & \multicolumn{2}{|c|}{ Heart Muscle } & \multicolumn{2}{|c|}{ Fat } \\
\hline & Total As $\left(\mu \mathrm{g} \mathrm{Kg}^{-1}\right)$ & \% Extraction & Total As $\left(\mu \mathrm{g} \mathrm{Kg}^{-1}\right)$ & \% Extraction \\
\hline & $151 \pm 7$ & $89 \pm 5$ & $99 \pm 5$ & $96 \pm 5$ \\
\hline $\mathbf{E X}-\mathrm{Ch}_{2}$ & $139 \pm 5$ & $88 \pm 5$ & $100 \pm 8$ & $94 \pm 5$ \\
\hline $\mathrm{EX}-\mathrm{Ch}_{3}$ & $150 \pm 6$ & $89 \pm 6$ & $99 \pm 6$ & $96 \pm 5$ \\
\hline $\mathrm{EX}-\mathrm{Ch}_{4}$ & $146 \pm 8$ & $89 \pm 6$ & $107 \pm 7$ & $94 \pm 6$ \\
\hline EX-Ch & $158 \pm 8$ & $95 \pm 6$ & $104 \pm 6$ & $96 \pm 6$ \\
\hline EX-Ch & $147 \pm 8$ & $96 \pm 8$ & $111 \pm 7$ & $95 \pm 5$ \\
\hline $\mathrm{NEX}-\mathrm{Ch}_{1}$ & $64 \pm 4$ & $86 \pm 5$ & $54 \pm 5$ & $93 \pm 7$ \\
\hline $\mathrm{NEX}-\mathrm{Ch}_{2}$ & $60 \pm 3$ & $88 \pm 5$ & $54 \pm 6$ & $90 \pm 5$ \\
\hline $\mathrm{NEX}-\mathrm{Ch}_{3}$ & $67 \pm 5$ & $86 \pm 5$ & $56 \pm 5$ & $91 \pm 5$ \\
\hline $\mathrm{NEX}-\mathrm{Ch}_{4}$ & $66 \pm 5$ & $86 \pm 5$ & $55 \pm 5$ & $92 \pm 5$ \\
\hline $\mathrm{NEX}-\mathrm{Ch}_{5}$ & $69 \pm .6$ & $89 \pm 6$ & $59 \pm 5$ & $94 \pm 5$ \\
\hline $\mathrm{NEX}-\mathrm{Ch}_{6}$ & $64 \pm 6$ & $87 \pm 4$ & $58 \pm 7$ & $94 \pm 7$ \\
\hline
\end{tabular}

EX-Ch: Chicken exposed to As(V), NEX-Ch: Non exposed chicken

The total As content in the most common chicken food, cornflower, for the non exposed chicken was about $50 \mu \mathrm{g} \mathrm{Kg}^{-1}$. However, the As content in the chicken feed used in the experiments with exposed chicken was lower than 10 $\mu \mathrm{g} \mathrm{Kg}^{-1}$. It was demonstrated that the As in the no exposed chicken was mainly contributed by the feed, as the As content in the drinking water was almost negligible.

\section{Arsenic Extraction Efficiency}

Different methanol:water mixtures $(1: 1,9: 1)$, using a focused ultrasonic bath, were tested as extractants. 1:1 methanol: water in two consecutive steps, followed by one extraction with 9:1 methanol:water gave transparent extracts and provided the best recovery for the As species tested, and was therefore chosen for further experiments. Table 3 shows the As extraction efficiency obtained for each tissue. These results show that most of the arsenic in the 
tissues examined was extracted by the 1:1 and 9:1 methanol-water-extracting solutions yield higher than $80 \%$ of As species in the heart tissues analysed in this work, suggest that intracellular As species can be extracted in these extracting mixtures; this has also been observed in other biological tissues ${ }^{16}$. Under these conditions, the arsenic species contained in these cells could be extracted and the arsenic speciation investigated. Most of the total arsenic concentrations were extracted in 1:1 methanol-water-extracting solution. The arsenic species stability was monitored during sample preparation and storage.

The arsenic content in the extracts, after their mineralization, was in the $85-95 \%$ range, depending on the tissue with respect to the total content. The arsenic content in the blanks was negligible.

Arsenic Species found in the different analysed tissues

For As speciation in samples, As(III), As(V), DMA, MMA and AsB species were separated by the above-mentioned anion gradient chromatographic method. Under the experimental conditions, all the species were well resolved Figure 1a.The general results of As species quantified in the different parts of the chicken analysed and some representative chromatograms for the heart muscle and fat are shown in Figures 1b-1e, and Table 4 respectively.

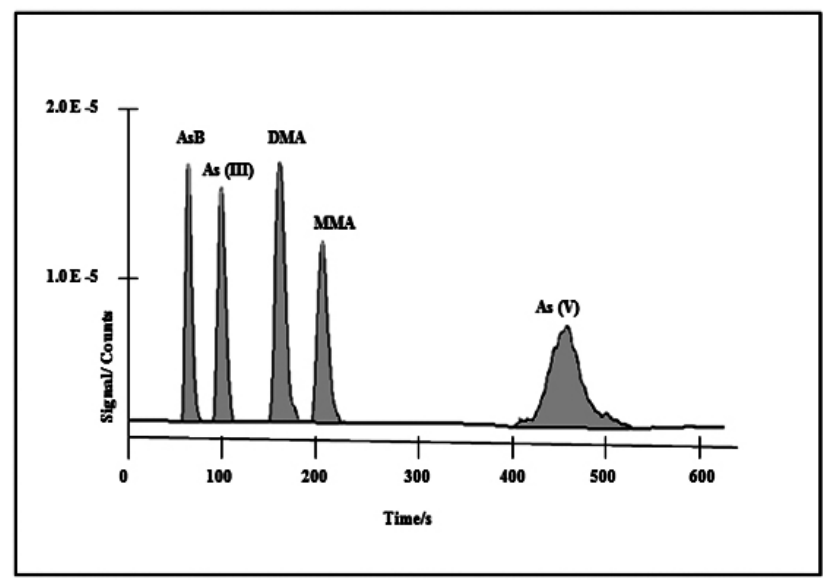

a) Mixture of As species containing $15 \mu \mathrm{g} \mathrm{L}$ - of AsB and $5 \mu \mathrm{g} \mathrm{L-1}$ of As (III), As (V), MMA and DMA species

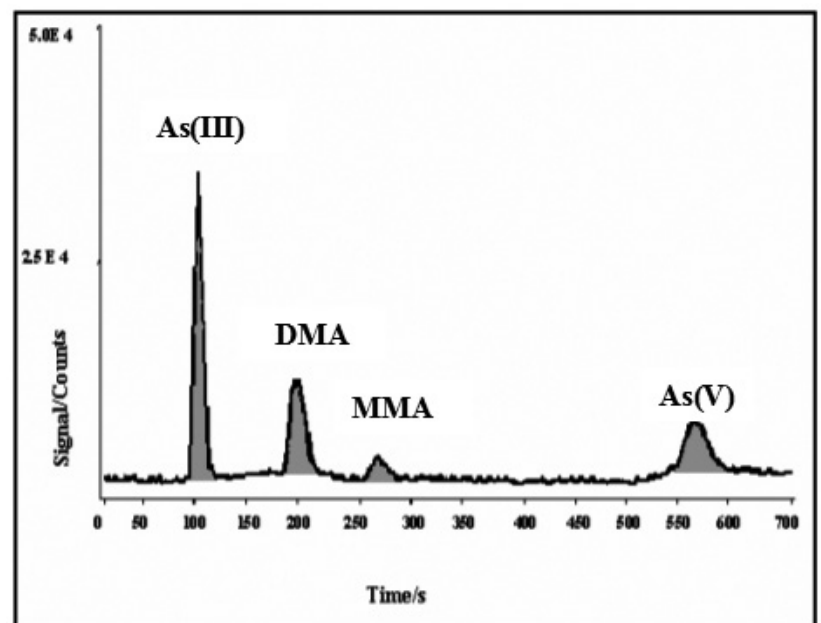

b) Exposed chicken Heart muscle

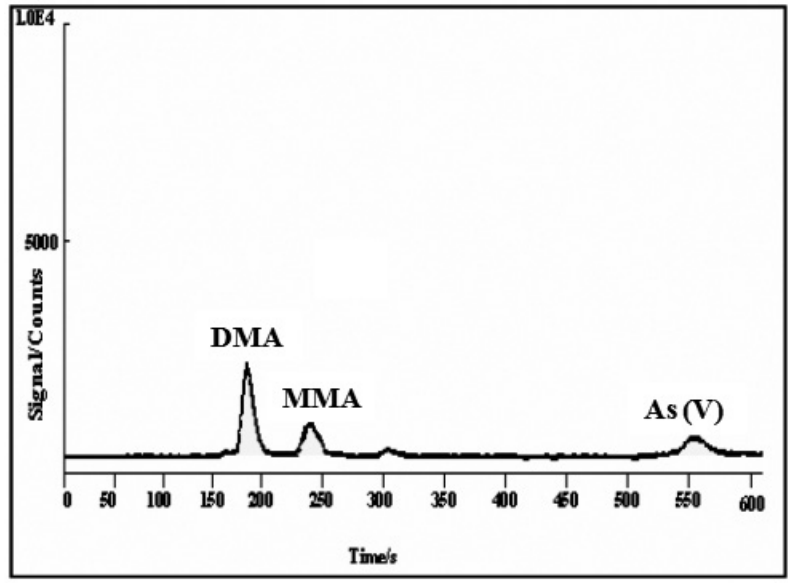

c) Non exposed chicken Heart muscle

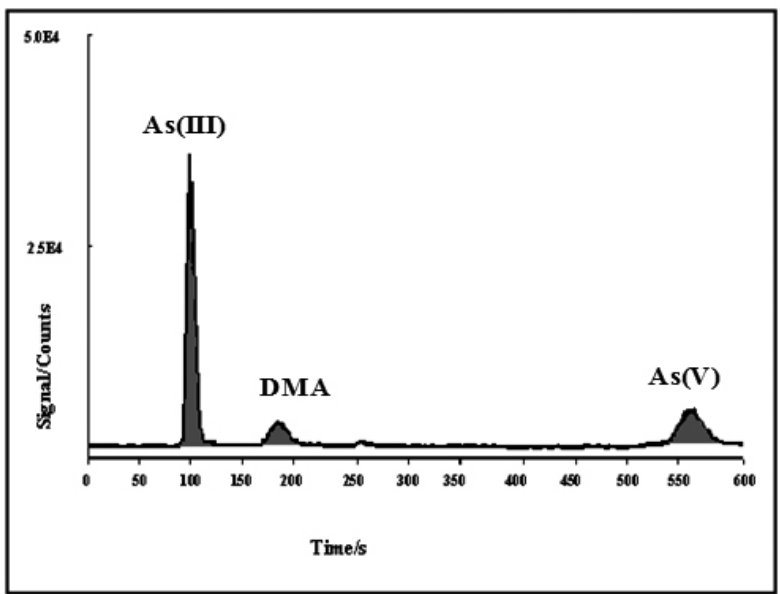

d) Exposed chicken fat

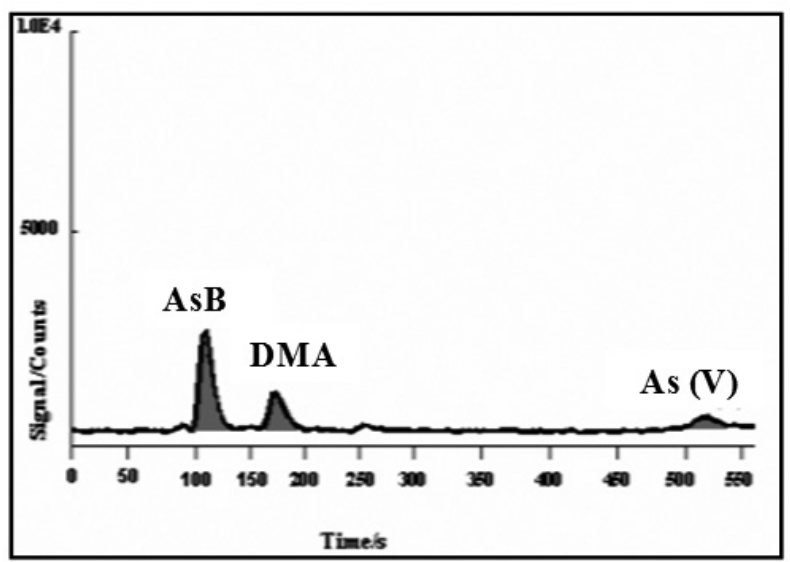

e) Non exposed chicken fat

Figure 1. HPLC -ICP-MS chromatogram for As species in: a) Mixture of As species containing $15 \mu \mathrm{g} \mathrm{L}^{-1}$ of AsB and $5 \mu \mathrm{g} \mathrm{L}^{-1}$ of As (III), As (V), MMA and DMA species

b) Exposed chicken Heart muscle

c) Non exposed chicken Heart muscle

d) Exposed chicken fat

e) Non exposed chicken fat 
Table 4: Concentration of As species in chicken tissue ( $\mu \mathrm{g} \mathrm{Kg}^{-1}$ of As ).

\begin{tabular}{|c|c|c|}
\hline Sample & Heart Muscle & Fat \\
\hline \multicolumn{3}{|l|}{$\mathrm{EX}-\mathrm{Ch}_{1}$} \\
\hline $\begin{array}{l}\mathrm{As}(\mathrm{III}) \\
\mathrm{As}(\mathrm{V}) \\
\mathrm{MMA} \\
\mathrm{DMA} \\
\text { AsB }\end{array}$ & $\begin{array}{c}32 \pm 3 \\
16 \pm 1 \\
\text { n.d. } \\
13 \pm 1 \\
\text { n.d. }\end{array}$ & $\begin{array}{c}20 \pm 3 \\
13 \pm 1 \\
\text { n.d } \\
12 \pm 1 \\
\text { n.d. }\end{array}$ \\
\hline \multicolumn{3}{|l|}{$\mathrm{EX}-\mathrm{Ch}_{2}$} \\
\hline $\begin{array}{c}\text { As(III) } \\
\text { As(V) } \\
\text { MMA } \\
\text { DMA } \\
\text { AsB }\end{array}$ & $\begin{array}{c}36 \pm 3 \\
15 \pm 1 \\
6 \pm 1 \\
15 \pm 1 \\
\text { n.d. }\end{array}$ & $\begin{array}{c}26 \pm 1 \\
10 \pm 1 \\
\text { n.d. } \\
11 \pm 1 \\
\text { n.d. }\end{array}$ \\
\hline \multicolumn{3}{|l|}{$\mathrm{EX}-\mathrm{Ch}_{3}$} \\
\hline $\begin{array}{c}\text { As(III) } \\
\text { As(V) } \\
\text { MMA } \\
\text { DMA } \\
\text { AsB }\end{array}$ & $\begin{array}{c}32 \pm 3 \\
15 \pm 1 \\
\text { n.d. } \\
13 \pm 1 \\
\text { n.d. }\end{array}$ & $\begin{array}{c}23 \pm 3 \\
12 \pm 1 \\
5 \pm 1 \\
16 \pm 1 \\
\text { n.d. }\end{array}$ \\
\hline \multicolumn{3}{|l|}{ E-Ch } \\
\hline $\begin{array}{c}\text { As(III) } \\
\text { As(V) } \\
\text { MMA } \\
\text { DMA } \\
\text { AsB }\end{array}$ & $\begin{array}{c}31 \pm 3 \\
15 \pm 1 \\
\text { n.d. } \\
13 \pm 1 \\
\text { n.d. }\end{array}$ & $\begin{array}{c}25 \pm 4 \\
11 \pm 1 \\
5 \pm 1 \\
16 \pm 1 \\
\text { n.d. }\end{array}$ \\
\hline \multicolumn{3}{|l|}{$\mathrm{EX}-\mathrm{Ch}_{5}$} \\
\hline $\begin{array}{c}\mathrm{As}(\mathrm{III}) \\
\mathrm{As}(\mathrm{V}) \\
\text { MMA } \\
\text { DMA } \\
\text { AsB }\end{array}$ & $\begin{array}{c}30 \pm 3 \\
14 \pm 1 \\
\text { n.d. } \\
12 \pm 1 \\
\text { n.d. }\end{array}$ & $\begin{array}{l}23 \pm 4 \\
12 \pm 1 \\
7 \pm 2 \\
18 \pm 4 \\
\text { n.d. }\end{array}$ \\
\hline \multicolumn{3}{|l|}{$\mathrm{EX}-\mathrm{Ch}_{6}$} \\
\hline $\begin{array}{c}\text { As(III) } \\
\text { As(V) } \\
\text { MMA } \\
\text { DMA } \\
\text { AsB }\end{array}$ & $\begin{array}{c}24 \pm 5 \\
14 \pm 2 \\
\text { n.d. } \\
12 \pm 1 \\
\text { n.d. }\end{array}$ & $\begin{array}{c}18 \pm 5 \\
13 \pm 2 \\
6 \pm 1 \\
17 \pm 3 \\
\text { n.d. }\end{array}$ \\
\hline \multicolumn{3}{|l|}{$\mathrm{NEX}-\mathrm{Ch}_{1}$} \\
\hline $\begin{array}{c}\mathrm{As}(\mathrm{III}) \\
\mathrm{As}(\mathrm{V}) \\
\mathrm{MMA} \\
\\
\mathrm{DMA} \\
\mathrm{AsB}\end{array}$ & $\begin{array}{c}\text { n.d } \\
6 \pm 1 \\
8 \pm 2 \\
16 \pm 1 \\
\text { n.d }\end{array}$ & $\begin{array}{c}\text { n.d } \\
5 \pm 1 \\
\text { n.d } \\
13 \pm 1 \\
14 \pm 3\end{array}$ \\
\hline $\mathrm{NEX}-\mathrm{Ch}_{2}$ & & \\
\hline
\end{tabular}

\begin{tabular}{|c|c|c|}
\hline $\begin{array}{c}\mathrm{As}(\mathrm{III}) \\
\mathrm{As}(\mathrm{V}) \\
\mathrm{MMA} \\
\\
\text { DMA } \\
\text { AsB }\end{array}$ & $\begin{array}{c}\text { n.d } \\
8 \pm 1 \\
4 \pm 1 \\
15 \pm 2 \\
\text { n.d }\end{array}$ & $\begin{array}{c}\text { n.d } \\
4 \pm 1 \\
\text { n.d } \\
8 \pm 2 \\
16 \pm 2\end{array}$ \\
\hline \multicolumn{3}{|l|}{$\mathrm{NEX}-\mathrm{Ch}_{3}$} \\
\hline $\begin{array}{c}\mathrm{As}(\mathrm{III}) \\
\mathrm{As}(\mathrm{V}) \\
\mathrm{MMA} \\
\text { DMA } \\
\text { AsB }\end{array}$ & $\begin{array}{c}\text { n.d. } \\
8 \pm 2 \\
7 \pm 1 \\
13 \pm 1 \\
\text { n.d. }\end{array}$ & $\begin{array}{c}\text { n.d } \\
4 \pm 1 \\
\text { n.d } \\
14 \pm 2 \\
13 \pm 3\end{array}$ \\
\hline \multicolumn{3}{|l|}{ NEX-Ch ${ }_{4}$} \\
\hline $\begin{array}{c}\text { As(III) } \\
\text { As(V) } \\
\text { MMA } \\
\text { DMA } \\
\text { AsB }\end{array}$ & $\begin{array}{c}\text { n.d. } \\
6 \pm 2 \\
5 \pm 1 \\
11 \pm 1 \\
\text { n.d. }\end{array}$ & $\begin{array}{c}\text { n.d } \\
4 \pm 1 \\
\text { n.d } \\
10 \pm 1 \\
12 \pm 1\end{array}$ \\
\hline \multicolumn{3}{|l|}{$\mathrm{NEX}-\mathrm{Ch}_{5}$} \\
\hline $\begin{array}{l}\text { As(III) } \\
\text { As(V) } \\
\text { MMA } \\
\text { DMA } \\
\text { AsB }\end{array}$ & $\begin{array}{c}\text { n.d. } \\
5 \pm 1 \\
7 \pm 1 \\
10 \pm 1 \\
\text { n.d. }\end{array}$ & $\begin{array}{c}\text { n.d } \\
4 \pm 1 \\
\text { n.d } \\
11 \pm 1 \\
12 \pm 1\end{array}$ \\
\hline \multicolumn{3}{|l|}{$\mathrm{NEX}-\mathrm{Ch}_{6}$} \\
\hline $\begin{array}{l}\text { As(III) } \\
\text { As(V) } \\
\text { MMA }\end{array}$ & $\begin{array}{c}\text { n.d. } \\
5 \pm 1 \\
6 \pm 2 \\
13 \pm 3 \\
\text { n.d. }\end{array}$ & $\begin{array}{c}\text { n.d } \\
5 \pm 1 \\
\text { n.d } \\
12 \pm 2 \\
11 \pm 1\end{array}$ \\
\hline
\end{tabular}

EX -Ch: Chicken exposed to As(V) NEX-Ch : non exposed chicken

The DMA species was present in all the exposed and non exposed chicken tissues analysed at a similar concentration level, which contrasts with the different values found for total As content (twice as high in the exposed chicken). This could be explained by the fact that DMA was released after reaching a certain concentration level in the tissue. The DMA concentration was about $10-35 \%$ of the total As content in the heart tissue. The methylation in chicken seems to be a favoured mechanism. The acid species was rather low or negligible for all tissues tested, which could be due to its fast transformation to DMA and/or its fast urinary excretion. The dimethylarsinic acid content is higher than that of MMA in animals fed with $\mathrm{As}(\mathrm{V})$ when there is high exposure to this species ${ }^{7}$.

The AsB content in the fat of non exposed chicken was relatively high. The presence of this species was unexpected; the AsB is formed only through microorganism activity. Thus, some uncontrolled microbial activity must have occurred. A very low $\mathrm{As}(\mathrm{V})$ content was also detected in practically all the heart tissues tested. In all cases, the percentage of $\mathrm{As}(\mathrm{V})$ was within the 7-13\% range of the total concentration.

It is important to mention that the most toxic As species, As(III) was the main species present in the heart tissues of the exposed chicken and represented $42 \%$ of the total As. However, for the control chicken, no As(III) species was found.

In a previous study on the determination of total As content and As species in heart tissues of inhabitants of the high As content Chilean II Region suffering from coronary thrombosis, the cardiac tissues showed the highest As(III) content, but was fifty times higher than that of the exposed chicken. However, although some DMA was present in the fat of the chicken, this species was not present in the aforementioned exposed human beings.

The bioaccumulation capacities of chicken after exposure to high As(V) 
is not considered to be very high taking into account that the concentrations found were at the same levels (double content) of nonexposed chicken. Similar experiments performed by Falnoga et al. ${ }^{8}$ on the liver of hens exposed to $\mathrm{As}_{2} \mathrm{O}_{3}$ found that the accumulation of As as DMA was much higher (435 $\left.\mathrm{ng} \mathrm{g}^{-1}\right)$ than that found in chicken heart and fat. The concentrations of other As species such as $\mathrm{As}(\mathrm{V}), \mathrm{MMA}$ or $\mathrm{As}(\mathrm{III})$ were almost negligible or below the detection limit. The difference in accumulation capacities between human and chicken heart tissues may be attributed to the difference in exposure time, which is about 5060 years for humans and only 50 days for chicken.

The arsenic speciation results in chicken heart tissues exposed to $\mathrm{As}(\mathrm{V})$ studied in this work shows the major As species found were As(III) and DMA, MMA and As (V) were only minor species. On the other hand, in pooled cardiovascular fat tissues non exposed AsB was the predominant species followed by DMA and $\mathrm{As}(\mathrm{V})$. The arsenic species were confirmed by spiking with the standard solutions of the species.

MMA and DMA are the main products of the cellular biomethylation through the conjugated effects of S - adenosylmethionine and the methyltransferase enzyme, however, the experimental results of this work don't allow discriminating against between As (III) and As (V) methylated species, the spiking additions were made with $\mathrm{As}(\mathrm{V})$ methylated arsenicals. $\mathrm{As}(\mathrm{V})$ is the main arsenic species present in natural waters enriched in arsenic, therefore the biotransformation of $\mathrm{As}(\mathrm{V})$ to $\mathrm{As}(\mathrm{III})$ must be a main mechanism in the organisms. Generally, MMA and DMA species has been considered important species in the arsenic detoxification mechanisms, then one surprising fact was that the DMA and MMA species were detected in the Exposed chicken heart muscle and the concentration of DMA were very low in the Exposed chicken fat. Similar results were found in cardiovascular tissues of patients with coronary heart disease ${ }^{27}$. AsB is believed to have a very low toxicity and has been found in human serum; the AsB presence was unexpected in this work, this organarsenical species enters to the human beings principally from marine foods and from agricultural products coming from polluted soils and / or watered with arsenic enriched waters ${ }^{28}$

Some hypothesis could be important for explaining the above results. In vivo methylation has long been proposed as an arsenic detoxification pathway for inorganic arsenic, however, it has been shown recently that As(III) - MMA and As(III) - DMA, two intermediates in the arsenate methylation are more toxic to cells than inorganic arsenic ions $\mathrm{As}(\mathrm{III})$ and $\mathrm{As}(\mathrm{V}){ }^{29}$. The metabolism of arsenic has an important role in its toxic effects, anyway arsenic is primarily metabolized in the liver and kidney, but not all mammalian species methylate inorganic arsenic, there is variations between species and among human populations in the rate and extent of methylation of inorganic arsenic ${ }^{30}$, guinea pigs, marmosets, tamarind monkeys, chimpanzees, etc. are unable to methylate arsenic ${ }^{31}$

The results obtained in this work would be indicating that for some reason arsenic enriched heart tissues probably they don't metabolize efficiently to arsenic, the inefficiency of the methylation mechanisms it could be due to the lack of methylating agents in these tissues, that which could favour a strong interaction of inorganic arsenic with arsenic - binding proteins of the cells; As binding proteins in heart tissues like these has been yet informed in As exposed persons ${ }^{32}$ and also has been informed that $\mathrm{As}(\mathrm{III})$ is the main species bound to proteins in intracellular solution of rat liver in which about one half of the methylated As species are bound to proteins ${ }^{32}$. Inorganic arsenic species have a high affinity for proteins containing conjugated sulphur groups and therefore extra cellular and intracellular proteins could bind As. The direct toxic effects of arsenic are thought to be the result of its interaction with sulfhydril groups in proteins ${ }^{33}$.

In particular, it is demonstrated that the heart muscle it is an "As(III) target tissue", which it is important because inorganic As(III) It is one of the most toxic chemical species of arsenic.

\section{Histological Study}

Figures 2 and 3 shows the histological plates for the heart muscle of a damaged and non-damaged tissue respectively. The vascular pathology, Figure 2 , is type concentric intimal fibrosis. This muscle-damage is presented in different grades and consists in the expansion of the internal surface due to miofibroblastos and due to this expand the light circumference is strongly reduced. In this case, the tissue is seriously ill and the intimal layer has analogous thickness than the muscular layer. The concentric intimal fibrosis does not belong to the principal atherosclerotic disease damage, main causes for heart attack and is produced by age, or by the influence of chemical or immunological processes ${ }^{34}$. Then, appear not to be apparent that arsenic may cause necrosis in cardiovascular tissues of the $\operatorname{man}^{35}$. However, at the light of the new knowledge, a critical issue is how to distinguish between apoptosis and necrosis ${ }^{36}$. The histochemical results reveal damage in the heart tissues, which could be involved in some type of dysfunction, which is clinically supported by the coronary angiography of the relatively young patients exposed to arsenic ${ }^{37}$.

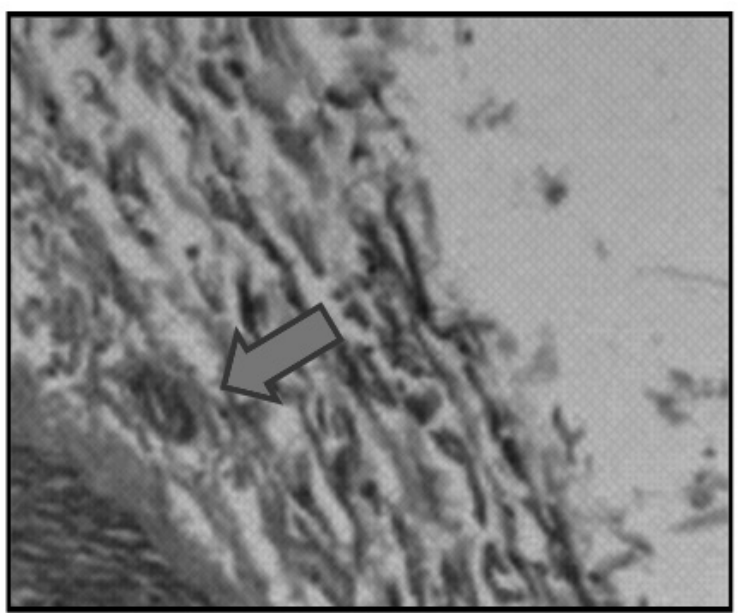

Figure 2. Histological study of a heart tissue suffering concentric an intimal fibrosis of chickens exposed to arsenic.

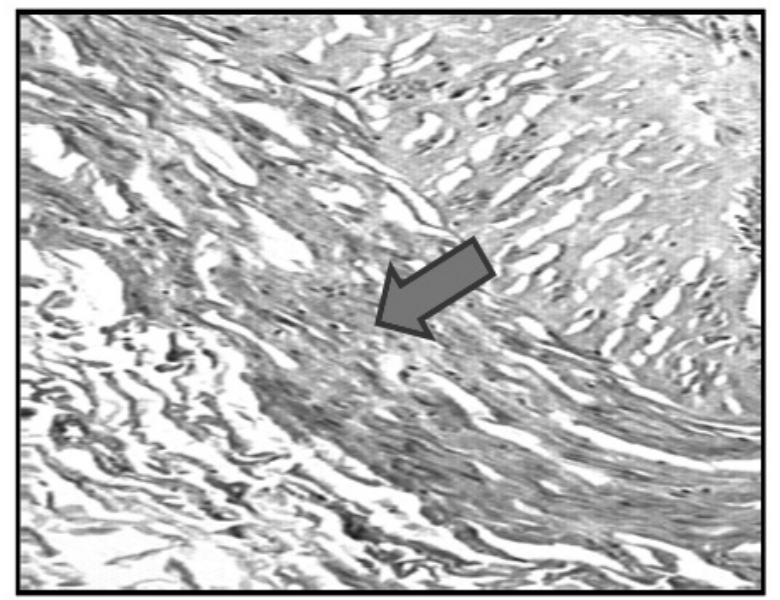

Figure3. Histological study of a normal heart tissue of chickens non exposed to arsenic.

\section{CONCLUSIONS}

The total As content and As species in similar tissues of each sample within the same set of chickens were very similar.

The biotransformation of the As(V) supplied to the chickens under study was observed. The As species were mainly distributed as follows: As(III) in the cardiac muscle and DMA in the fat. Furthermore, a high percentage of arsenate was present in all the cardiac tissues. For the control chickens obtained in the supermarket, the As content in all the tissues was half that found in the chickens exposed to As. Also, the presence of As(III) was not detected in any of the chickens not exposed to As.

Since inorganic arsenic is always found as a main component in some tissues, it means that the methylation detoxification mechanism is not always possible in cell tissues, which may increase the As impact risk.

The presence of a high As(III) concentration in the heart tissues of humans and the fact this is the main As species in the cardiac tissues of the exposed chicken suggests that chicken might be used as a representative animal when considering As exposure in humans. 


\section{REFERENCES}

1.- E.F. Winterbottom, D.L. Fei, D.C. Koestler, C. Giambelli, E. Wika, A. J. Capobianco, E. Lee, C. J. Marsit, M.R. Karagas, D.J. Robbins. Ebomedicine. 2, 536 - 543,(2015)

2.- I. Pizarro, D. Román-Silva, C. Solar, M.M. Gómez, C. Cámara, M.A. Palacios. J. Chil. Chem. Soc. 57, 1181- 1188, (2012)

3.- J.S. Tsuji, V. Perez, M.R. Garry, D.D. Alexander. Toxicology. 323, 78 - 94, (2014).

4.- E.M. Muehe, A. Kappler. Environ. Chem. 11,483 - 495, (2014)

5.- A. Khan, H.I. Hussain, A. Sattar, M. Z. Khan, R.Z. Abbas. Int. J.Agic .Biol. 16, 1213 - 1224, (2014)

6.- I. Pizarro, D.A. Román-Silva, M. Gómez, C. Cámara, M.A. Palacios. J. Chil.Chem.Soc.50, 2071 - 2076, ( 2013)

7.- L. Muñoz, M. Meneses, P. Pismante, O. Andonie, F. Queirolo, S. Stegen. J. Chil.Chem.Soc.59, 2432 - 2436, ( 2014)

8.- I. Falnoga, V. Stibij, M. Tusek-Znidaric, Z. Slejkovec, D. Masej, R. Jacimovic, J.Scancar. J. Biological Trace Element Research. 78, 241 254 (2000).

9.- F. Stea, F. Bianchi, L. Cori, R. Sicari. Environmental Science and Pollution Research. 21, 244-251, (2014)

10.- N.V. Solenkova, J.D. Newman, J.S. Berger, G. Thurston, J.S. Hochman, G.A. Lamas. American Heart Journal. 168, 812 - 822, (2014)

11.- P. Sánchez - Virosta, S. Espin, A.J. García - Fernández, T. Eeva. Science of the Total Environment. 512 - 513, 506 - 525, (2015)

12.- J.R, Downs, P.G. O'Malley. Annals of Internal Medicine. 163, 291- 298, (2015)

13.- K. Moon, E. Guallar, A. Navas-Ancien. Curr Atheroscler Rep 14, $542-$ $555,(2012)$

14.- United Nations Environmental Program (UNEP). Determination of Total Selenium in Selected Marine organisms by Hydride Generation Atomic Absorption Spectrometry. Reference Method for Marine Pollution Studies $\mathrm{N}^{\circ} 10,1984$

15.- B. Welz, M. Melcher. Anal. Chem. 57, 427 - 431,(1985)

16.- Y. Shibata, M. Morita. Appl. Organomet. Chem. 6, 340 - 343, (1992)

17.- B. Mobini. Veterinarni Medicina. 57, $404-409,(2012)$

18.- A. S. Mohammod Noman, S. Dilruba, N. C. Mohanto, L. Rahman, Z. Khatun, W. Riad, A. A. Mamun, S. Alam, S. Aktar, S. Chowdhury, Z. A. Saud, Z. Rahman, K. Hossain. J Cytol Histol. 6, doi:10.4172/21577099.1000323, (2015)

19.- G. Sharma, M. Kumar. Asian Pacific Journal of Reproduction. 3, $282-$ 287, (2014)

20.- A. Wares, A. Awal, S. Kumar, A. Hannan, A. Anas, A. Latif, N. Masud. J. Adv Vet Anim Res. 2, 128 - 133, (2015)

21.- A. Shrivastava, V. Gupta. Chronicles of Young Scientists. 2, $21-25$, (2011)

22.- P. De Biévre. Accred Qual Assur. 19,141-143, (2014)

23.- K. E. Nachman, P. A. Baron, G. Raber, K. A. Francesconi, A. Navas-Acien, D. C. Love, J. Hopkins. Environmental Health Perspectives. 121, 818824, (2013)

24.- R. Wahlen, S. McSheehy, C. Scriver, Z. Mester. J. Anal. A. Spectrom.19, $876-882,(2004)$

25.- M. A. Morgano, L. C. Rabonato, R. F. Milani, L. Miyagusku, S. C. Balian. Food Control. 22, $778-785,(2011)$

26.- K. J. Mercer, K. R. Bradley, W. L. Burns. The FASEB Journal, 27, $574-$ $577,(2013)$

27.- D.A. Román, I. Pizarro, L. Rivera, C. Cámara, M.A. Palacios, M.M Gómez, C. Solar. Hum Exp Toxicol. 30, 1150 - 1164, (2011)

28.- M. Pigna, A. G. Caporale, L. Cavalca, A. Sommella, A. Violante. Environmental Engineering Science. 32, 551- 563, (2015)

29.- Y. Li, D. Wang, X. Li, Q. Zheng, G. Sun. Int. J. Environ. Res. Public Health.12, 3615-3632, (2015)

30.- J. E. Laine, K. A. Bailey, M. Rubio-Andrade, A. F. Olshan, L. Smeester, Z. Drobná, A. H. Herring, M. Stýblo, G. G. García-Vargas, R. C. Fry. Environ Health Perspect. 123, $186-192$, (2015)

31.- K. Takahashi, H. Yamauchi, M. Mashiko, Y. Yamamura. Japanese Journal of Hygiene. 45, $613-618$. (2015)

32.- A. A. Ajees, B. P. Rosen. Geomicrobiology Journal. 32, 570 - 576, (2015)

33.- M. Hoffmann, C. Mikutta, R. Kretzschmar. Environ. Sci. Technol. 48, 3822-3831, (2014)

34.- C. Solar, I. Pizarro, D. Román. Rev Chil Cardiol. 31,41 - 47, (2012)

35.- K. Gaim , G. Gebru, S. Abba. International Journal of Scientific and Research Publications, 5, 1-9, (2015)
36.- Z. Xian, S. Ming Lei, Y. Yu Ting, D. Jia, N. Xiu Shi. Int J Clin Exp Med. 8, $7667-7672,(2015)$

37.- M. F. Naujokas, B. Anderson, H. Ahsan, H. V. Aposhian, J. H. Graziano, C. Thompson, W. A. Suk. Environmental Health Perspectives. 121, 295 $302,(2013)$ 